\title{
Safety, efficacy and cost of intra-operative cell salvage during open radical prostatectomy
}

\author{
Jennifer $\mathrm{Xu}^{1 \wedge}$, Ned Kinnear ${ }^{1,2}$, Lydia Johns Putra ${ }^{1,2}$ \\ ${ }^{1}$ Department of Urology, Ballarat Base Hospital, Ballarat, Australia; ${ }^{2}$ St John of God Hospital, Ballarat, Australia \\ Contributions: (I) Conception and design: N Kinnear; (II) Administrative support: J Xu, N Kinnear; (III) Provision of study materials or patients: All \\ authors; (IV) Collection and assembly of data: J Xu, N Kinnear; (V) Data analysis and interpretation: J Xu, N Kinnear; (VI) Manuscript writing: All \\ authors; (VII) Final approval of manuscript: All authors. \\ Correspondence to: Dr. Jennifer Xu. Ballarat Base Hospital, 1 Drummond St North, Ballarat Central, VIC 3350, Australia. Email: Jennifer.xu@mh.org.au.
}

Background: We aim to examine the safety and efficacy of intra-operative cell salvage (ICS) in radical prostatectomy.

Methods: A retrospective cohort study was performed, enrolling consecutive patients undergoing open radical prostatectomy at two institutions during 01/01/18-31/12/19. Patients were grouped by ICS use. Primary outcomes were allogeneic transfusion rates, and biochemical recurrence (prostate specific antigen $>0.2 \mathrm{mg} / \mathrm{mL}$ ). Secondary outcomes were use of adjuvant therapies, Clavien-Dindo complications and transfusion-related cost (allogeneic transfusion + ICS setup + ICS reinfusion).

Results: In total, 168 men were enrolled. Patients were grouped based on whether they received no blood conservation technique (126 men) or ICS (42 men). Groups were similar in median age, pre- and postoperative haemoglobin and length of stay. They also had similar post-operative tumour Gleason score, TNM-stage and positive surgical margin rates. Compared with controls, the ICS group had shorter follow up (336 vs. 225 days; $\mathrm{P}=0.003)$. The groups had similar rates of biochemical recurrence (17\% vs. 14\%; $\mathrm{P}=0.90)$, adjuvant therapy use $(30 \%$ vs. $29 \% ; \mathrm{P}=0.85)$ and complications ( $14 \%$ vs. $19 \%$ patients; $\mathrm{P}=0.46)$. There was no metastatic progression or cancer-specific mortality in either group. Although a similar proportion of patients received allogenic transfusion $(2.4 \%$ vs. $4.8 \% ; \mathrm{P}=0.33)$ and units of packed red blood cells (PRBC) (9 vs. 5 units), transfusion-related costs were higher amongst the ICS group (AUD \$11,422 vs. $\$ 43,227)$.

Conclusions: ICS use in radical prostatectomy was not associated with altered rates of allogeneic transfusion, complications, biochemical recurrence or adjuvant or salvage therapies. Transfusion related costs were higher in the ICS group.

Keywords: Prostatectomy; cell salvage; autologous; transfusion; blood; cost

Submitted Sep 13, 2020. Accepted for publication Jan 27, 2021.

doi: $10.21037 /$ tau-20-1265

View this article at: http://dx.doi.org/10.21037/tau-20-1265

\section{Introduction}

Prostate cancer is the most commonly diagnosed noncutaneous cancer in men. In 2020, incidence is expected to exceed 25,000 men in Australia, and 240,000 in the United States of America, with over one third undergoing prostatectomy (1-3). Traditionally, radical prostatectomy has been associated with significant operative blood loss. This has improved over recent decades, due to the introduction of minimally invasive technologies, improved anatomical understanding and advances in surgical technique. However,

^ ORCID 0000-0001-8452-0713. 
estimated blood loss in open prostatectomy remains significant at $900 \mathrm{~mL}$, with allogeneic blood transfusion (ABT) rates of $4-14 \%$ in modern series (4-6).

The accessibility and safety of ABT in developed nations have dramatically improved in the past thirty years. However, patients undergoing transfusions remain exposed to a broad range of risks. These include fluid overload, transfusion reaction, ABO incompatibility, transfusion transmitted infections, storage errors, delayed administration and death (7). Additionally, ABT has been shown to induce transfusion related immuno-modulation and increased cancer recurrence, including urological $(8,9)$. The cost of administering a single unit of packed red blood cells (PRBC) also continues to rise, recently exceeding AUD \$1,100 (10,11).

Intra-operative cell salvage (ICS) offers a sound alternative to ABT and avoids many of its limitations. Spilled blood is scavenged from the operative field, washed, filtered and transfused back to the patient. ICS has repeatedly been demonstrated safe in oncological surgery, and effective in reducing $\mathrm{ABT}$ rates and transfusion-related cost (12-15). Despite these advantages, ICS has not found universal favour, due to concerns of unclear efficacy and tumour recurrence.

To date, the literature on ICS use in radical prostatectomy consists of twelve retrospective studies of median size 107 patients, with most published $>15$ years ago $(10,14)$. Therefore, this study aims to undertake a large and contemporary assessment of patients undergoing open radical prostatectomy, examining the effect of ICS use on safety, efficacy and cost. We present the following article in accordance with the STROBE reporting checklist (available at http://dx.doi.org/10.21037/tau-20-1265).

\section{Methods}

In this retrospective cohort study, consecutive patients undergoing open radical prostatectomy at either of our two institutions between 01/01/18-31/12/19 were enrolled. Data were collected from hospital and private practice electronic and hard copy records. Post-operative surveillance for biochemical recurrence (BCR) was performed at least every six months, based on tumour stage and grade. BCR was defined as a post-operative prostate specific antigen of $>0.2 \mathrm{ng} / \mathrm{mL}$. Data census occurred at 30/03/20. Last follow-up data was determined from date of last clinical appointment.

Patients were grouped and compared based on whether they did (ICS group) or did not (control) receive ICS. Primary outcomes were oncological safety (assessed by biochemical recurrence with post-operative prostate specific antigen of $>0.2 \mathrm{ng} / \mathrm{mL}$ ) and efficacy (assessed by allogeneic transfusion rates). Secondary outcomes were use of adjuvant or salvage therapies, Clavien-Dindo complications of any grade (16) and transfusion-related cost. The study had Institutional Ethics Review approval (LNR/62339/ BHSSJOG-2020-206251).

\section{ICS practice}

In our department, the decision to utilise ICS for a procedure is based on surgeon preference, taking into account anticipated blood loss and personal preference. At both sites, the ICS machine is a Sorin Xtra ${ }^{\circledR}$ (LivaNova, London), using a Imugard ${ }^{\circledR}$ III-RC leukocyte depletion filter (Terumo Corporation, Tokyo).

As recommended by other authors, our institutions both use ICS in a financially tiered system. Initially only equipment required for the blood salvage, anticoagulation and collection are opened. When desired, further equipment is opened to allow blood processing and reinfusion. This allows costs savings, with the ICS processor set and other items not wasted when blood is not reinfused.

The decision to reinfuse salvaged blood is made jointly by the surgeon and anaesthetist, based on patient preoperative haemoglobin, cardiorespiratory comorbidities, intra-operative heart rate and blood pressure, volume of blood salvaged and anticipated future haemorrhage risk.

\section{Transfusion related cost calculations}

Costs were calculated as of 30/03/20 (Table 1). Transfusion related costs were calculated as allogeneic transfusion cost + ICS setup cost + ICS reinfusion cost. Costs related to length of stay and complications were not included.

Allogeneic transfusion incurs both product and process costs. The product cost of one PRBC unit at our institution is AUD \$416.15, purchased from the National Blood Authority (17). Process costs of transfusion include hospital overheads, staffing, pre-infusion laboratory testing and inhospital logistics. These are known to be three to five times higher than the product cost $(18,19)$. Australian process costs were first estimated in 2006 at AUD $\$ 370$ per unit of allogeneic red blood cells infused (20). Several authors have subsequently applied the Australian Bureau of Statistics consumer price index for hospital and medical services to 
Table 1 The cost of intra-operative cell salvage set up and reinfusion in Australian dollars, as of 31 March 2020

\begin{tabular}{lc}
\hline Item & Cost \\
\hline Ballarat Base Hospital & \\
ICS collection reservoir alone & $\$ 160.00$ \\
Dual suction tubing & $\$ 25.00$ \\
Anticoagulant & $\$ 7.40$ \\
Waste Bag & $\$ 36.40$ \\
Sub-total, ICS setup cost & $\$ 228.80$ \\
ICS combined collection + processing kit & $\$ 380.00^{\dagger}$ \\
Leucocyte depletion filter & $\$ 31.24$ \\
Blood reinfusion bag & $\$ 9.90$ \\
3x1 L 0.9\% normal saline & $\$ 2.97$ \\
Intra-venous infusion tubing & $\$ 8.90$ \\
Sub-total, ICS reinfusion cost & $\$ 433.01$ \\
St John of God Hospital & $\$ 19.64$ \\
ICS collection reservoir alone & $\$ 198.15$ \\
Dual suction tubing & $\$ 140.00^{\dagger}$ \\
Anticoagulant & $\$ 160.00$ \\
Sub-total, ICS setup cost & $\$ 25.00$ \\
ICS combined collection + processing kit & $\$ 10.25$ \\
\hline Blood reinfusion bag & $\$ 195.25$ \\
\hline Intra-venous infusion tubing & $\$ 3.27$ \\
\hline
\end{tabular}

${ }^{\dagger}$, cost of reservoir alone subtracted from the cost of the combined ICS kit, as the latter equipment bundle includes a reservoir. amp., ampoules; ICS, intra-operative cell salvage; $\mathrm{mL}$, millilitres.

derive modern re-estimates of this cost, updated in 2010 to AUD $\$ 536(10,11,21)$. We applied this same method to estimate a $59.1 \%$ increase from end-of-financial-year 2010 to 2019 (22). This resulted in a current process cost of AUD $\$ 853$, and a total cost of AUD $\$ 1,269.15$ per unit allogeneic red blood cells infused.

ICS costs were calculated by pricing each item involved. At both centres, sufficient capacity in routine theatre technician staffing and the existence of only one ICS machine per site mean that no additional staffing costs were incurred to deliver ICS.

\section{Statistical analysis}

Most primary and secondary outcomes were categorical measures, including number of patients per group experiencing biochemical recurrence, allogeneic transfusion and complications. These categorical measures were summarized as proportions and assessed with Pearson's chi-square test, unless zero values were encountered, in which case Fisher's exact test was used. Continuous data such as serum haemoglobin were summarized as medians, and groups were compared using the Wilcoxon (MannWhitney) test. All tests were two-tailed and significance was assessed at the $5 \%$ alpha level. Data were analysed using SAS v9.3 (SAS Institute Inc., Cary, NC, USA).

\section{Ethics}

This study was conducted in accordance with the Declaration of Helsinki (as revised in 2013). The study was approved by the Ballarat Health Services and St John of God Healthcare Human Research Ethics Committee (LNR/62339/BHSSJOG-2020-206251) and individual consent for this retrospective analysis was waived.

\section{Results}

\section{Demographics}

One hundred and sixty-eight consecutive patients underwent open radical prostatectomy during the study period and were enrolled. No blood conservation technique occurred for 126 men, while ICS was employed for 42. Patient characteristics, tumour characteristics, primary outcomes and secondary outcomes are summarised in Table 2.

\section{Primary outcome 1-oncological safety}

The control and ICS groups had similar rates of biochemical recurrence ( 21 vs. 6 patients; $\mathrm{P}=0.90$ ). There was no metastatic progression or cancer-specific mortality in either group.

\section{Primary outcome 2-efficacy}

The control and ICS groups had equivalent use of allogeneic transfusion ( 3 vs. 2 patients; $\mathrm{P}=0.33$ ). This included nine and five units of allogeneic red blood cells 
Table 2 Patient characteristics and outcomes

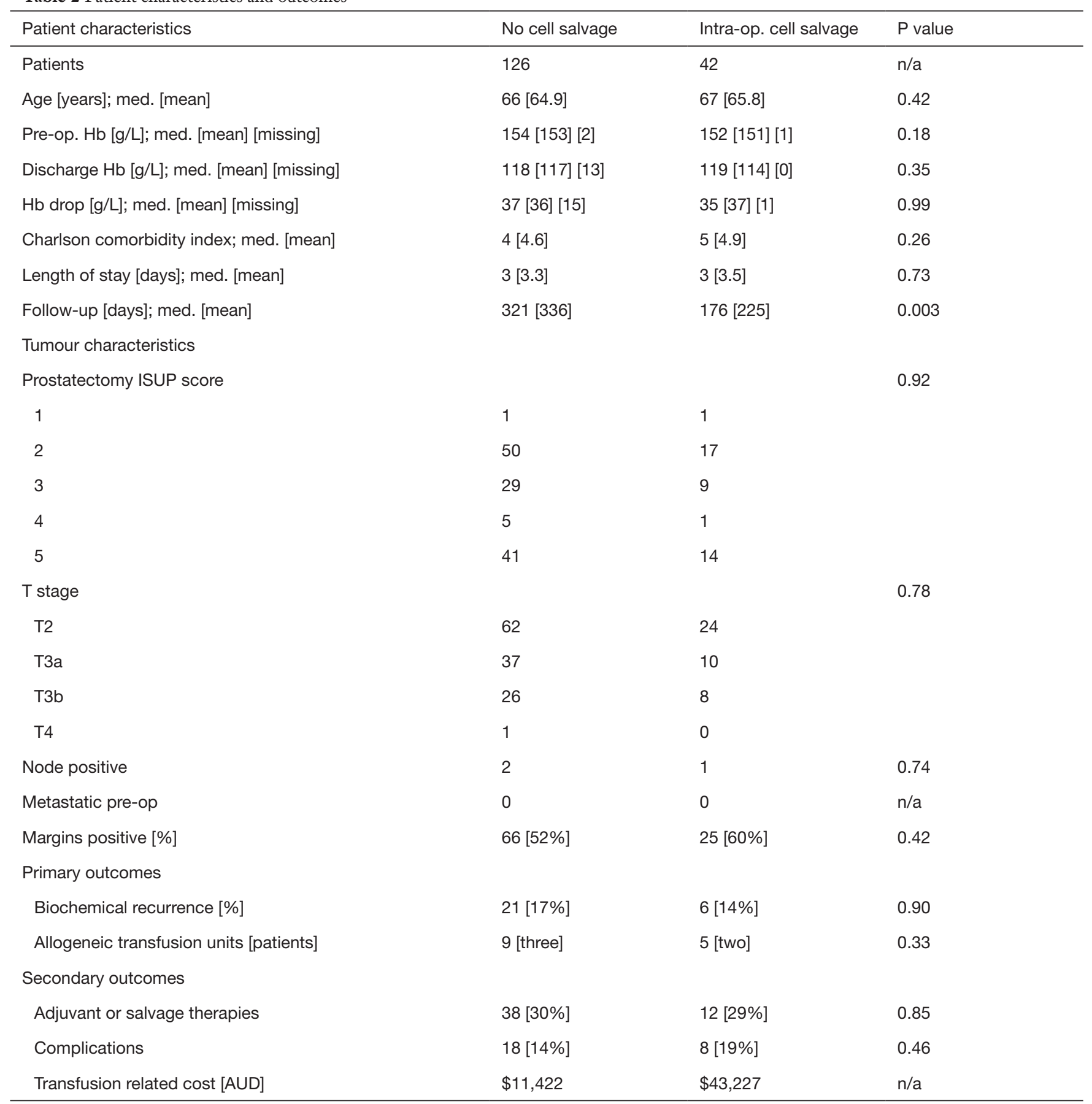

NB. Continuous variables: Mann Whitney U. Categorical variables with no zero values: chi square test. Categorical variables with any zero values: Fisher exact test. Data given as median [interquartile range]. AUD, Australian dollars; Hb, haemoglobin; ISUP, International Society of Urological Pathology; n/a, not applicable; Op, operative. 
Table 3 Complications

\begin{tabular}{|c|c|c|}
\hline Complications & Clavien-Dindo grade & No. \\
\hline Hypoglycaemia, ward based care with electrolytes & I & 1 \\
\hline Hypotension, ward based care with electrolytes & I & 7 \\
\hline lleus, ward based care with electrolytes, no NGT & I & 1 \\
\hline High drain output requiring extended period with drain & I & 3 \\
\hline Delirium, ward based care with medications & II & 1 \\
\hline Fever \& pelvic abscess, requiring antibiotics only & $\|$ & 1 \\
\hline Hypotension, requiring inotropes in recovery only, no ICU & II & 1 \\
\hline \multicolumn{3}{|l|}{ Intra-operative cell salvage group } \\
\hline Hypotension, ward based care with electrolytes & I & 2 \\
\hline Ileus, ward based care with electrolytes, no NGT & I & 1 \\
\hline High drain output requiring extended period with drain & I & 1 \\
\hline Rectal perforation repaired during prostatectomy & Illb & 1 \\
\hline Arrhythmia requiring ICU admission & IV & 1 \\
\hline Hypotension requiring ICU admission & IV & 1 \\
\hline Bowel injury + urinoma, requiring return to theatre \& ICU admission & IV & 1 \\
\hline
\end{tabular}

ICU, intensive care unit; IUC, indwelling urethral catheter; NGT, naso-gastric tube.

transfused, respectively.

\section{Secondary outcomes}

Adjuvant or salvage therapies were used in 38 and twelve patients respectively $(\mathrm{P}=0.85)$. The groups had similar rates of complications (18 vs. 8 patients; $\mathrm{P}=0.46$ ) (Table 3), with no deaths at time of data census. Regarding costs, 19 and 45 patients had salvaged blood collection alone at our public and private institution respectively. A separate 27 and 15 men had reinfusion of salvaged blood at these sites. Including costs of the units of allogeneic blood transfusion described in 'Primary outcomes', transfusion related costs were higher for the ICS group (AUD \$11,422 vs. \$43,227).

\section{Discussion}

Intra-operative blood loss remains a challenge in radical prostatectomy despite modern advances. In addition to ABT and ICS, several other blood-conservation management strategies exist, including pre-operative autologous blood donation and acute normovolaemic haemodilution. However, these both have significant limitations and are rarely practiced. Pre-operative autologous blood donation is twice as expensive as autologous blood, requires several pre-operative visits to prepare, decreases preoperative haemoglobin and $50 \%$ of pre-donated units are discarded (15). Conversely, despite being more cost effective compared to pre-operative autologous blood donation, acute normovolaemic haemodilution is often complicated by intra-operative hypotension $(15,23)$. ICS avoids these pitfalls and offers many additional benefits. It does not require pre-operative visits, nor cause pre-operative anaemia or intra-operative hypotension. Fresh salvaged red cells have greater oxygen carrying capacity than stored red cells (24). 
Despite its multiple advantages, ICS remains controversial due to misconceptions regarding its efficacy and safety, particularly in tumour surgery. In 1986, the American Medical Association of Scientific Affair recommended against the use of ICS in cancer surgery following publication of a 1975 case report, in which a patient with lung cancer died from diffuse metastasis four weeks post pneumonectomy with ICS use $(25,26)$. However, multiple studies have since generated strong and robust scientific evidence to contradict this hypothesis and validate the safety of ICS in oncological surgery $(13,14)$. Part of this success has been the routine incorporation of a leukocyte depletion filter to eliminate almost all tumour cells scavenged from the operative field (27). Subsequently, use of ICS in radical prostatectomy is supported by multiple healthcare institutions such as the National Blood Authority Australia (28), the American Association of Blood Banks (29), the United Kingdom's National Institute for Health and Care Excellence (NICE) (30) and the Association of Anaesthetists of Great Britain and Ireland (31), whose guidelines are endorsed by the Royal College of Surgeons.

This study represents the largest assessment to date of ICS in prostatectomy in the Southern Hemisphere. Findings from our study show that ICS use does not affect rates of biochemical recurrence, use of adjuvant therapies or complication rates. This is in keeping with evidence from three large audits previously reporting complication rates associated with ICS use to be as low as $<0.3 \%(32-34)$. Indeed, existing meta-analysis of blood conservation strategies in oncological surgery have revealed higher rates of disease recurrence with allogeneic transfusion $(8,9)$, but not ICS $(13,14)$. Amongst all twelve comparative studies to date of ICS in radical prostatectomy, with study follow up ranging 0-64 months (median 36 months), groups receiving ICS have experienced similar or decreased rates of biochemical recurrence compared with controls $(10,14)$.

In this study, ICS use did not affect rates of ABT. This is consistent with similar works. While three prior studies of ICS in prostatectomy have reported significantly reduced $\mathrm{ABT}$ rates (35-37), most have not (10,37-45). In our patients, we believe this is related to the high median pre-operative haemoglobin $(152-154 \mathrm{~g} / \mathrm{L})$, low rates of transfusion in both groups (2-5\%) and small sample size.

Additionally, this study showed that transfusion related costs were higher in the ICS group compared to control. This is likely due to the low transfusion rates in the control arm, with subsequent limited capacity to deliver savings. This result was surprising given the absence of ICSrelated staffing costs in our centre, in contrast to other studies $(10,11)$. Amongst pre-existing studies of ICS in prostatectomy, only one found increased cost associated with ICS use (38), while all others have reported reduced expense $(10,37,46)$. These findings have prompted reconsideration of patient selection in our centre. In future, the decision to salvage blood will be based on body habitus, pre-operative haemoglobin and intra-operative findings after dissection of the space of Retzius.

This study is limited by its small sample size and retrospective nature. While our group's median followup was short at 6 to 11 months, the authors do not expect a longer observation period to change the study's findings. However, we remain optimistic that the shorter period of follow up amongst the ICS group represents higher uptake in the latter half of the enrolment period and highlights a growing confidence among employing use of ICS. Despite similarities in patient and disease characteristics between the comparison groups, the non-randomised methodology may be associated with a degree of selection bias. Given the increasing utilisation of robot assisted radical prostatectomy, future studies are needed to investigate the relevance of ICS in this arena.

\section{Conclusions}

Within the limitations of this small retrospective study, ICS use in radical prostatectomy was not associated with altered rates of allogeneic transfusion, complications, biochemical recurrence or adjuvant or salvage therapies. Transfusion related costs were higher in the ICS group.

\section{Acknowledgments}

The authors thanks to theatre technicians Jake Warren and Kane Crocker for their help obtaining pricing data. Funding: None.

\section{Footnote}

Reporting Checklist: The authors have completed the STROBE reporting checklist. Available at http://dx.doi. org/10.21037/tau-20-1265

Data Sharing Statement: Available at http://dx.doi. 
org/10.21037/tau-20-1265

Conflicts of Interest: All authors have completed the ICMJE uniform disclosure form (available at http://dx.doi. org/10.21037/tau-20-1265). The authors have no conflicts of interest to declare.

Ethical Statement: The authors are accountable for all aspects of the work in ensuring that questions related to the accuracy or integrity of any part of the work are appropriately investigated and resolved. The study was conducted in accordance with the Declaration of Helsinki (as revised in 2013). This study was conducted in accordance with the Declaration of Helsinki (as revised in 2013). The study was approved by the Ballarat Health Services and St John of God Healthcare Human Research Ethics Committee (LNR/62339/BHSSJOG-2020-206251) and individual consent for this retrospective analysis was waived.

Open Access Statement: This is an Open Access article distributed in accordance with the Creative Commons Attribution-NonCommercial-NoDerivs 4.0 International License (CC BY-NC-ND 4.0), which permits the noncommercial replication and distribution of the article with the strict proviso that no changes or edits are made and the original work is properly cited (including links to both the formal publication through the relevant DOI and the license). See: https://creativecommons.org/licenses/by-nc-nd/4.0/.

\section{References}

1. Australian Institute of Health and Welfare. Prostate cancer in Australia. AIHW, Canberra. 2013. Available online: https://www.aihw.gov.au/reports/cancer/prostatecancer-in-australia/contents/summary. Accessed Accessed 01/05/2020.

2. Brawley OW. Prostate cancer epidemiology in the United States. World J Urol 2012;30:195-200.

3. Lowrance WT, Eastham JA, Savage C, et al. Contemporary open and robotic radical prostatectomy practice patterns among urologists in the United States. J Urol 2012;187:2087-92.

4. Rabbani F, Yunis LH, Pinochet R, et al. Comprehensive standardized report of complications of retropubic and laparoscopic radical prostatectomy. Eur Urol 2010;57:371-86.

5. Paul R, Busch R, van Randenborgh H, et al. Influence of blood transfusions during radical retropubic prostatectomy on disease outcome. Urology 2006;67:137-41.

6. Schmitges J, Sun M, Abdollah F, et al. Blood transfusions in radical prostatectomy: a contemporary population-based analysis. Urology 2012;79:332-8.

7. Bolton-Maggs P, Poles D. The 2016 Annual SHOT Report (2017). Serious Hazards of Transfusion. 2017. Available online: https://www.shotuk.org/wp-content/ uploads/SHOT-Report-2016_web_11th-July.pdf. Accessed 01 September 2017.

8. Wang YL, Jiang B, Yin FF, et al. Perioperative Blood Transfusion Promotes Worse Outcomes of Bladder Cancer after Radical Cystectomy: A Systematic Review and MetaAnalysis. PLoS One 2015;10:e130122.

9. Li SL, Ye Y, Yuan XH. Association between Allogeneic or Autologous Blood Transfusion and Survival in Patients after Radical Prostatectomy: A Systematic Review and Meta-Analysis. PLoS One 2017;12:e171081.

10. Kinnear N, Heijkoop B, Hua L, et al. The impact of intraoperative cell salvage during open radical prostatectomy. Transl Androl Urol 2018;7:S179-87.

11. Kinnear N, Hua L, Heijkoop B, et al. The impact of intraoperative cell salvage during open nephrectomy. Asian J Urol 2019;6:346-52.

12. Carless PA, Henry DA, Moxey AJ, et al. Cell salvage for minimising perioperative allogeneic blood transfusion. Cochrane Database Syst Rev 2010:CD001888.

13. Waters JH, Yazer M, Chen YF, et al. Blood salvage and cancer surgery: a meta-analysis of available studies. Transfusion 2012;52:2167-73.

14. Kinnear N, O'Callaghan M, Hennessey D, et al. Intraoperative cell salvage in urological surgery; a systematic review and meta-analysis of comparative studies. BJU Int 2019;123:210-9.

15. Davies L, Brown TJ, Haynes S, et al. Cost-effectiveness of cell salvage and alternative methods of minimising perioperative allogeneic blood transfusion: a systematic review and economic model. Health Technol Assess 2006;10:iii-iv, ix-x, 1-210.

16. Dindo D, Demartines N, Clavien PA. Classification of surgical complications: a new proposal with evaluation in a cohort of 6336 patients and results of a survey. Ann Surg 2004;240:205-13.

17. National Blood Authority Australia. What Blood Products are Supplied - National Product List. NBA, Canberra. 2017. Available online: https://www.blood.gov.au/nationalproduct-list. Accessed Accessed 01/05/20.

18. Shander A, Hofmann A, Ozawa S, et al. Activity-based costs of blood transfusions in surgical patients at four 
hospitals. Transfusion 2010;50:753-65.

19. Leahy MF, Trentino KM, May C, et al. Blood use in patients receiving intensive chemotherapy for acute leukemia or hematopoietic stem cell transplantation: the impact of a health system-wide patient blood management program. Transfusion 2017;57:2189-96.

20. Wood E, Bielby L, Hunt R, et al. editors. O116 Transfusing a Unit of Red Cells - What Does It Really Cost in Australia? 2008 Haematology Society of Australia and New Zealand Annual Scientific Meeting; 2008; Perth, Australia.

21. Leahy MF, Mukhtar SA. From blood transfusion to patient blood management: a new paradigm for patient care and cost assessment of blood transfusion practice. Intern Med J 2012;42:332-8.

22. Australian Bureau of Statistics. Consumer price index, hospital and medical services; Australia (A2329041T). ABS, Canberra. 2020. Available online: https://www.abs. gov.au/ausstats/meisubs.nsf/log?openagent\&640101. xls\&6401.0\&Time\%20Series\%20Spreadsheet\&199C A54C56CEED5BCA2585B3001F2D25\&0\&June \%20 2020\&29.07.2020\&Latest. Accessed Accessed 01/05/20.

23. Monk TG, Goodnough LT, Brecher ME, et al. Acute normovolemic hemodilution can replace preoperative autologous blood donation as a standard of care for autologous blood procurement in radical prostatectomy. Anesth Analg 1997;85:953-8.

24. Ray JM, Flynn JC, Bierman AH. Erythrocyte survival following intraoperative autotransfusion in spinal surgery: an in vivo comparative study and 5-year update. Spine (Phila Pa 1976) 1986;11:879-82.

25. Council on Scientific Affairs. Autologous blood transfusions. JAMA 1986;256:2378-80.

26. Yaw PB, Sentany M, Link WJ, et al. Tumor cells carried through autotransfusion. Contraindication to intraoperative blood recovery? JAMA 1975;231:490-1.

27. Wiesel M, Gudemann C, Staehler G, et al. Separation of urologic tumors cells from Cell Saver blood using a membrane filter. A new method in autotransfusion? Urologe A 1992;31:182-5.

28. National Blood AuthorityAustralia. Guidance for the provision of intraoperative cell salvage. 2014. Available online: https://www.blood.gov.au/system/files/documents/ ics-guidance-march-2014_1.pdf. Accessed Accessed 01/05/20.

29. American Association of Blood Banks. Standards for Perioperative Autologous Blood 8th edn. AABB, Bethesda. 2013. Available online: http://www.aabb.org/resources/
marketplace/Documents/183100_pre.pdf. Accessed Accessed 01/05/20.

30. National Institute for Health and Care Excellence. Intraoperative red blood cell salvage during radical prostatectomy or radical cystectomy; Interventional procedures guidance [IPG144]. National Health Service, London. 2008. Available online: https://www.nice.org.uk/ guidance/ipg258. Accessed Accessed 01/05/20.

31. Association of Anaesthetists of Great Britain and Ireland. Intra-operative Cell Salvage. AAGBI, London. 2009.

Available online: https://www.google.com.au/url?sa=t\&rc $\mathrm{t}=\mathrm{j} \& \mathrm{q}=\&$ esrc $=\mathrm{s} \&$ source $=$ web \& $\mathrm{cd}=2$ \&ved=0ahUKEwiQ8s Hv65TXAhUJIJQKHQaACBIQFggtMAE\&url=https\%3 A $\% 2$ F\% 2Fwww.aagbi.org\%2Fsites\%2Fdefault $\% 2 F$ files\% 2Fcell\%2520_salvage_2009_amended.pdf\&usg=AOvVaw3 9LQkP72BqbtpSzlwpc_cm. Accessed Accessed 01/05/20.

32. DeAndrade D, Waters JH, Triulzi DJ, et al. Very low rate of patient-related adverse events associated with the use of intraoperative cell salvage. Transfusion 2016;56:2768-72.

33. Domen RE. Adverse reactions associated with autologous blood transfusion: evaluation and incidence at a large academic hospital. Transfusion 1998;38:296-300.

34. Linden J. Autologous blood errors and incidents (abstract). American Association of Blood Banks. 47 Annual Meeting November 12-17, 1994: Transfusion; 1994. p. 28S.

35. Gray CL, Amling CL, Polston GR, et al. Intraoperative cell salvage in radical retropubic prostatectomy. Urology 2001;58:740-5.

36. Nieder AM, Manoharan M, Yang Y, et al. Intraoperative cell salvage during radical cystectomy does not affect longterm survival. Urology 2007;69:881-4.

37. Ubee SS, Manikandan R, Gudimetla AR, et al. Cost benefits of intraoperative cell salvage in radical cystectomy. Indian J Urol 2010;26:196-9.

38. Gilbert JB, Malkowicz SB, Wein AJ. Cell saver and radical retropubic prostatectomy: analysis of cost-effectiveness. Urology 1995;46:542-4.

39. Chiusano MA, Finkelstein LH, Mene M, et al. Use of predeposited autologous blood plus intraoperative autotransfusion compared with use of predeposited autologous blood alone in radical retropubic prostatectomy. J Am Osteopath Assoc 1996;96:160-4.

40. Davis M, Sofer M, Gomez-Marin O, et al. The use of cell salvage during radical retropubic prostatectomy: does it influence cancer recurrence? BJU Int 2003;91:474-6.

41. Waters JH, Lee JS, Klein E, et al. Preoperative autologous donation versus cell salvage in the avoidance of allogeneic transfusion in patients undergoing radical retropubic 
prostatectomy. Anesth Analg 2004;98:537-42, table of contents.

42. Nieder AM, Carmack AJ, Sved PD, et al. Intraoperative cell salvage during radical prostatectomy is not associated with greater biochemical recurrence rate. Urology 2005;65:730-4.

43. MacIvor D, Nelson J, Triulzi D. Impact of intraoperative red blood cell salvage on transfusion requirements and outcomes in radical prostatectomy. Transfusion 2009;49:1431-4.

44. Raval JS, Nelson JB, Woldemichael E, et al. Intraoperative cell salvage in radical prostatectomy does not appear to increase long-term biochemical recurrence, metastases, or mortality. Transfusion 2012;52:2590-3.

45. Lyon TD, Ferroni MC, Turner RM, 2nd, et al. Short-term Outcomes of Intraoperative Cell Saver Transfusion During Open Partial Nephrectomy. Urology 2015;86:1153-8.

46. Ubee S, Kumar M, Athmanathan N, et al. Intraoperative red blood cell salvage and autologous transfusion during open radical retropubic prostatectomy: a cost-benefit analysis. Ann R Coll Surg Engl 2011;93:157-61.

Cite this article as: $\mathrm{Xu} J$, Kinnear N, Johns Putra L. Safety, efficacy and cost of intra-operative cell salvage during open radical prostatectomy. Transl Androl Urol 2021;10(3):1241-1249. doi: $10.21037 /$ tau-20-1265 